\title{
Viral lysis of Phaeocystis pouchetii: Implications for algal population dynamics and heterotrophic $\mathbf{C}, \mathrm{N}$ and $\mathrm{P}$ cycling
}

\author{
Jakob Haaber ${ }^{1}$ and Mathias Middelboe \\ Marine Biological Laboratory, University of Copenhagen, Helsingør, Denmark
}

\begin{abstract}
A model ecosystem with two autotrophic flagellates, Phaeocystis pouchetii and Rhodomonas salina, a virus specific to $P$. pouchetii $(\mathrm{PpV})$ and bacteria and heterotrophic nanoflagellates was used to investigate effects of viral lysis on algal population dynamics and heterotrophic nitrogen and phosphorus mineralization. Lysis of $P$. pouchetii by PpV had strong positive effects on bacterial and HNF abundance, and the mass balance of $C, N$ and $P$ suggested an efficient transfer of organic material from $P$. pouchetii to bacterial and HNF biomass through viral lysis. At the same time, the degradation of $P$. pouchetii lysates was associated with significant regeneration of inorganic $N$ and $P$ resulting in $148 \mu \mathrm{g} \mathrm{N}^{-1}$ and $7 \mu \mathrm{g} \mathrm{Pl}^{-1}$, corresponding to $78 \%$ and $26 \%$ of lysate $\mathrm{N}$ and $\mathrm{P}$ being mineralized to $\mathrm{NH}_{4}^{+}$and $\mathrm{PO}_{4}^{3-}$, respectively. These results showed that the turnover of viral lysates in the microbial food web was associated with significant $\mathbf{N}$ and $\mathbf{P}$ mineralization, supporting the current view that viral lysates can be an important source of inorganic nutrients in marine systems. In the presence of $R$. salina, the generated $\mathrm{NH}_{4}^{+}$supported $11 \%$ of the observed $R$. salina growth. Regrowth of virus-resistant $\boldsymbol{P}$. pouchetii following cell lysis was observed in long-term incubations (150 days), and possibly influenced by nutrient availability and competition from $R$. salina. The observed impact of viral activity on autotrophic and heterotrophic processes provides direct experimental evidence for virus-driven nutrient generation and emphasizes the potential importance of the viral activity in supporting marine primary production.
\end{abstract}

The ISME Journal (2009) 3, 430-441; doi:10.1038/ismej.2008.125; published online 8 January 2009

Subject Category: microbial population and community ecology

Keywords: alga-virus interaction; algal succession; lysates; nutrient mineralization; resistance; nanoflagellates

\section{Introduction}

The potential influence of viruses on phytoplankton mortality and population dynamics is well known for marine environments (for example, Bratbak et al., 1993, 1995; Brussaard et al., 1996b, 2007), as verified by demonstrations of virus-induced termination of algal blooms (for example, Bratbak et al., 1993; Tarutani et al., 2000; Castberg et al., 2001; Brussaard et al., 2005b), and the potential of viruses as controlling agents for keeping algal populations at non-blooming levels (for example, Zingone et al., 1999; Larsen et al., 2001; Brussaard et al., 2005b).

Viral control of a specific algal population will leave an ecological niche exploitable for other algal species. This has been shown to occur for blooming

Correspondence: M Middelboe, Marine Biological Laboratory, University of Copenhagen, Strandpromenaden 5, DK-3000 Helsingør, Denmark.

E-mail: mmiddelboe@bio.ku.dk

${ }^{1}$ Current address: Center for Systems Microbiology, Bldg 301, Technical University of Denmark, Lyngby, Denmark

Received 4 August 2008; revised 13 November 2008; accepted 17 November 2008; published online 8 January 2009 algae (Bratbak et al., 1993; Castberg et al., 2001) and non-blooming algae (Larsen et al., 2001), thus demonstrating viruses as a driving force in algal succession. As viral lysis may influence phytoplankton population dynamics, algal resistance to viral infection could potentially be an important parameter in the selective forces that contribute to structuring phytoplankton communities. Growing evidence that viral control of bacterial hosts selects for virus-resistant bacteria under controlled conditions in culture experiments (for example, Middelboe, 2000; Middelboe et al., 2001; Mizoguci et al., 2003), have suggested that viral activity contributes to the high clonal diversity often observed in aquatic systems (for example, Comeau et al., 2006; Holmfeldt et al., 2007; Stenholm et al., 2008). Resistance to viral infection has also been demonstrated in populations of cyanobacteria.(Waterbury and Valois, 1993; Suttle and Chan, 1994; Lennon et al., 2007), as well as in eukaryotic algae (Tarutani et al., 2000; Jacquet et al., 2002; Schroeder et al., 2003; Thyrhaug et al., 2003). For Phaeocystis, the morphology of the cells (solitary vs colonial) has been shown to influence susceptibility to viral control, with single 
cells being much more vulnerable to viral infection than colonial cells (Brussaard et al., 2007). Resistance against specific viruses may also be caused by mutational changes in individual cells of Phaeocystis pouchetii, as demonstrated by the growth of such resistant $P$. pouchetii cells after population lysis and a subsequent long-term coexistence of $P$. pouchetii and its specific virus in culture experiments (Thyrhaug et al., 2003). However, still little is known about the physiological and molecular characteristics of virus-resistant algae, their competitive ability compared with the sensitive wild type and their role in natural environments.

Following viral lysis, labile cell contents are released as dissolved organic matter, which may be utilized with high efficiency by heterotrophic bacteria and thus stimulate heterotrophic growth and nutrient cycling (Fuhrman, 1992; Gobler et al., 1997; Bratbak et al., 1998a; Middelboe et al., 2003; Brussaard et al., 1996a, 2005a, 2007). During decomposition of algal lysates in the microbial food web, $\mathrm{N}$ and $\mathrm{P}$ and other nutrients in the lysates may become mineralized and released as inorganic forms. By this lateral transfer, algal lysates may function as a nutrient link to non-infected phytoplankton (for example, Bratbak et al., 1994; Poorvin et al., 2004; Brussaard et al., 2007, 2008; Middelboe, 2008). Thus, in addition to the direct impact on the mortality of individual algal species, viral lysis may stimulate growth of competing algal populations in the community by supplying regenerated nutrients. However, the effect of mineralized nutrients on algal growth shows large variations between different experiments, thus demonstrating the complexity of even apparently simple systems (Rothhaupt, 1992; Carlsson et al., 1999; del Giorgio and Cole, 2000) and at present there exist only few direct estimates of the role of viruses for the recycling of nutrients and stimulation of algal production (for example, Poorvin et al., 2004).

In this study we used an experimental model system containing the two autotrophic flagellates Phaeocystis pouchetii and Rhodomonas salina to examine the effects of viral lysis of $P$. pouchetii on (1) the growth of the co-occurring non-infected R. salina, (2) the cycling of nitrogen and phosphorus in the microbial food web and (3) the regrowth of virus-resistant $P$. pouchetii following lysis of the sensitive wild type.

\section{Materials and methods}

\section{Algal cultures}

The two algal species used in this study were Rhodomonas salina (Cryptophyceae), obtained from the culture collection at Marine Biological Laboratory, University of Copenhagen, Denmark and Phaeocystis pouchetii (Prymnesiophyceae = Haptophyceae) strain AJ01 obtained from the culture collection at the University of Bergen,
Norway. Stock cultures of the algae were grown non-axenically in $\mathrm{f} / 2$ medium (Guillard, 1975) based on aged seawater (34\%o), which was heated to $80{ }^{\circ} \mathrm{C}$ (40 $\mathrm{min}$ ) to eliminate biological contamination and at the same time avoid precipitation of the salts that can occur when heating to higher temperatures. The stock cultures were kept at $6{ }^{\circ} \mathrm{C}$ and at illumination rates of ca., $20 \mu \mathrm{mol}$ photons $\mathrm{m}^{-2} \mathrm{~s}^{-1}$. The experimental cultures were inoculated with exponentially growing algae, which had been acclimated for 2-7 days to the higher light intensities used in the experiments. A preliminary experiment revealed that algal growth was negatively affected at $\mathrm{pH}$ values exceeding 8.6. In all subsequent experiments initial $\mathrm{pH}$ was 7.3 and regular measurements ensured that $\mathrm{pH}$ never exceeded 8.6.

The lytic virus, PpV01, infecting $P$. pouchetii $(\mathrm{PpV})$ was obtained from the University of Bergen and stored at $5{ }^{\circ} \mathrm{C}$. Fresh virus stocks were prepared by infecting exponentially growing cultures of $P$. pouchetii, followed by centrifugation $(10 \mathrm{~min}$, $5000 \times g)$ and filtration $(0.45 \mu \mathrm{m}$ Osmonics syringe filter) of the lysate. Bacteria and HNF were present in algal stock cultures and were, therefore, transferred to the experiments with the algal inoculum. These heterotrophic communities were used as indicators of the effects of viral lysis on heterotrophic growth.

\section{Experimental setup}

This study consisted of two experiments designed to address different questions. In Experiment 1, we wanted to investigate the algal population dynamics of infected and non-infected phytoplankton. The cultures were manipulated with different initial virus/alga ratios, which allowed us to simulate different magnitudes of viral impact during bloom development and to investigate the subsequent differences in the effects of viral lysis on the system. In Experiment 2 the main focus was to couple the algal population dynamics and viral activity to the heterotrophic response, and to measure the fluxes of inorganic nitrogen and phosphorus in response to viral lysis and subsequent heterotrophic activity. Following measurements of heterotrophic activity during the first 41 days of incubation, the experiment was continued for another 110 days to investigate the long-term regrowth of resistant $P$. pouchetii cells after lysis of the initial virussensitive population in relation to inorganic nutrient concentration and coexistence with $R$. salina.

Experiment 1: To examine the influence of PpVvirus on the dynamics of $P$. pouchetii and $R$. salina, five batch cultures with different combinations of the two algae and PpV were established (Table 1). All cultures were established in duplicate and the experiment was run in $1 \mathrm{~L}$ Erlenmeyer flasks as non-axenic batch cultures in seawater medium (SWM) containing $800 \mathrm{ml}$ aged and heated $\left(80^{\circ} \mathrm{C}\right.$, $40 \mathrm{~min})$ seawater $(34 \%)$. For this and all subsequent 
Table 1 Experimental set up

\begin{tabular}{|c|c|c|c|c|c|}
\hline & Culture 1 & Culture 2 & Culture 3 & Culture 4 & Culture 5 \\
\hline & \multicolumn{5}{|c|}{ Treatment } \\
\hline Experiment 1 & P. pouchetii & R. salina & $\begin{array}{l}\text { P. pouchetii+ } \\
\text { R. salina }\end{array}$ & $\begin{array}{l}\text { P. pouchetii+ } \\
\text { R. salina+PpV } \\
(\mathrm{v} / \mathrm{a}=0.5)\end{array}$ & $\begin{array}{l}\text { P. pouchetii+ } \\
\text { R. salina } \mathrm{PpV} \\
(\mathrm{v} / \mathrm{a}=0.005)\end{array}$ \\
\hline Experiment 2 & $\begin{array}{l}\text { P. pouchetii+PpV } \\
\text { (f/2 medium) }\end{array}$ & $\begin{array}{l}\text { P. pouchetii+PpV } \\
\text { (SWM medium) }\end{array}$ & $\begin{array}{l}\text { P. pouchetii+ } \\
\text { R. salina }+\mathrm{PpV}(\mathrm{SWM})\end{array}$ & P. pouchetii (SWM) & - \\
\hline
\end{tabular}

experiments, the same batch of SWM was used. Algal cells were inoculated from exponentially growing cultures in $f / 2$ medium (maximum growth rate $=0.5 \mathrm{~d}^{-1}$ for both species) to give initial algal abundances of $2 \times 10^{4} \mathrm{P}$. pouchetii $\mathrm{ml}^{-1}$ and $2 \times 10^{3}$ $R$. salina $\mathrm{ml}^{-1}$. To ensure addition of equal amounts of nutrients to all cultures, sterile filtered $(0.02 \mu \mathrm{m}$, Whatman anotop 25) $R$. salina culture was added to the $P$. pouchetii control culture. Likewise sterile filtered $P$. pouchetii culture was added to the $R$. salina control culture. In total $70 \mathrm{ml}$ algal inoculate (live + sterile filtered) was added to a final volume of $870 \mathrm{ml}$ in the experimental cultures.

By inoculating algae growing in $\mathrm{f} / 2$ medium (N/P $\sim 10$ ), the seawater medium was enriched with nutrients, $\mathrm{NO}_{3}^{-}(10 \mu \mathrm{M})$ and $\mathrm{PO}_{4}^{3-}(1 \mu \mathrm{M})$, corresponding to levels of eutrophic Danish waters. In addition, vitamins and trace elements corresponding to full $\mathrm{f} / 2$ concentration were added to all cultures. Cultures were incubated at $6{ }^{\circ} \mathrm{C}$ and at an illumination rate from fluorescent tubes (warm white) of ca., $60 \mu \mathrm{mol}$ photons $\mathrm{m}^{-2} \mathrm{~s}^{-1}$ measured inside the bottles with a radiation sensor (QSL-101, Biospherical Instruments Inc.). All cultures were incubated with a light/dark cycle of 16:8 h. During the light period, a fan prevented the fluorescent tubes from warming up the cultures.

Samples for enumeration of algae and viruses were collected for 23 days. In the same period $\mathrm{pH}$ was monitored in all cultures and never exceeded 8.3. Before each sampling the cultures were gently swirled to ensure even distribution of the cells.

Experiment 2: Exponentially growing cells of $P$. pouchetii and $R$. salina and $\mathrm{PpV}$ were inoculated in different media to make four batch cultures in duplicate (Table 1). In all the virus-treated cultures, the initial virus/alga ratio was 0.005 . The experiment was carried out in $1 \mathrm{~L}$ Erlenmeyer flasks using the same experimental conditions as in Experiment 1 , and samples were collected for 18-41 days. $P$. pouchetii and $R$. salina were enumerated in all cultures to which they were added. Development in $\mathrm{PpV}$ abundance was systematically determined in culture 2, whereas PpV production only was verified occasionally during the incubations in culture 1 and 3 to verify an increase in $\mathrm{PpV}$ abundance concomitant with the observed decline in $P$. pouchetii abundance.
To examine the heterotrophic response to lysate production and the potential for nitrogen mineralization, we determined bacterial and heterotrophic nanoflagellate (HNF) abundances as well as ammonium, nitrate and phosphorus concentrations in cultures 2 and 3 . In the control culture without viruses (culture 4), only bacterial abundance was quantified to verify that the microbial response in cultures 2 and 3 was associated with lysate production.

Cultures containing both $P$. pouchetii and $\mathrm{PpV}$ (culture 1, 2 and 3) were then continued for another 110 days with regular collection of samples for determination of $P$. pouchetii and $R$. salina abundances to examine the long-term potential of $P$. pouchetii to develop resistance against $\mathrm{PpV}$ and the ability of such resistant cells to establish viable populations in cultures with different nutrient levels and competition for these nutrients. $\mathrm{pH}$ during this period did not exceed 7.8 in any of the cultures. When regrowth of $P$. pouchetii was observed in the SWM culture on day 80, an experiment was conducted to test if the viruses present in the culture were infective. Ten milliliters of the recovered culture was centrifuged $(15 \mathrm{~min}, 2500 \times \mathrm{g}$ ) and the supernatant was filtered $(0.45 \mu \mathrm{m}$ Osmonics syringe filter) before it was added to $100 \mathrm{ml}$ of an exponentially growing stock culture of wild type $P$. pouchetii. This experiment confirmed that the viruses in the cultures were infective to wild type $P$. pouchetii and present in significant abundances $\left(>10^{6} \mathrm{PpV} \mathrm{ml}{ }^{-1}\right)$ throughout the incubation (data not shown).

\section{Enumeration of organisms}

Algae. Subsamples for algal abundance were preserved in lugol $\left(5^{\circ} \mathrm{C}\right.$ acidic lugol's solution, final concentration $2.5 \%$ ). Immediately following fixation, the algae were counted using a SedgewickRafter S52 sedimentation chamber and an Olympus CK 40 inverted microscope. For all samples a minimum of 300 cells were counted. The detection limit using this method was approximately 20 cells $\mathrm{ml}^{-1}$.

Viruses. Virus counts in Experiments 1 and 3 were performed by epifluorescense microscopy. Samples 
were preserved with glutaraldehyde $(0.5 \%$ final concentration) and immediately filtered onto $0.02 \mu \mathrm{m}$ filters (Whatman anodisc 25). The samples were then stained with SYBR Green I (Molecular Probes) using the method of Noble and Fuhrman (1998), mounted on glass slides and kept at $-20^{\circ} \mathrm{C}$. Within a few days the PpV abundance was then determined by counting at least $400 \mathrm{PpV}$ particles on each slide at $\times 1000$ using an Olympus BX 50 epifluorescense microscope. Owing to their larger genome (and therefore much brighter fluorescence) $\mathrm{PpV}$ was easily distinguished from bacteriophages.

In all experiments the estimates of $\mathrm{PpV}$ abundances were based on direct counts and the abundance of infective viruses is therefore probably lower due to significant variation in the infectivity of viral particles (Bratbak et al., 1998b). The same batch of virus lysate was used for inoculation in all experimental cultures and the percent infectivity of the virus particles in these lysates is therefore assumed to be similar.

Bacteria (Experiment 2). Bacteria were enumerated using a FACSCalibur flowcytometer (BD Biosciences, Franklin Lakes, NJ, USA) equipped with an air-cooled laser providing $15 \mathrm{~mW}$ at $488 \mathrm{~nm}$ and with standard filter setup. Samples were fixed in glutaraldehyde (final concentration $=0.5 \%$ ), frozen in liquid nitrogen and stored at $-80^{\circ} \mathrm{C}$ until further analysis. For analysis the samples were thawed and diluted 1-100 fold in TE buffer (Tris $10 \mathrm{~mm}$, EDTA $1 \mathrm{mM}, \mathrm{pH}$ 8). The samples were then stained with SYBR Green I (Molecular Probes) for $10 \mathrm{~min}$ at $80^{\circ} \mathrm{C}$ in the dark and run for 60 to $90 \mathrm{~s}$ in the flowcytometer with the discriminator at green fluorescence and a flow rate of $25.5 \mu \mathrm{lmin}{ }^{-1}$. Care was taken not to exceed an event rate of $800 \mathrm{~s}^{-1}$ in which case the sample was diluted and run again. The flow rate was calibrated by measuring the weight of removed fluid during fixed time intervals. Data was analyzed using CYTOWIN software (Vaulot, 1989).

Heterotrophic nanoflagellates (HNF) (Experiment 2). Samples were preserved with glutaraldehyde (2\% final concentration) and stained with DAPI (Porter and Feig, 1980). To prevent aggregation of cells, each sample was treated with ultrasound for $15 \mathrm{~s}$ (Vibra Cell, Sonics and Materials Inc.). A test was made verifying that no significant decline in cell abundance due to cell disintegration occurred using this method. Following the ultrasound treatment samples were filtered onto $0.22 \mu \mathrm{m}$ polycarbonate filters (Osmonics), mounted on glass slides and frozen at $-20^{\circ} \mathrm{C}$ until counting within 1 month. In each sample at least $300 \mathrm{HNF}$ cells (except for initial samples containing very few HNF) were enumerated at $\times 1000$ using an Olympus BX 50 epifluorescense microscope. In Experiment 2 additional enumeration of resistant $P$. pouchetii cells was made using the epifluorescense microscope thereby detecting the autofluorescent chloroplasts. The detection limit for all cells counted in the epifluorescense microscope was $\sim 200$ cells $\mathrm{ml}^{-1}$.

\section{Inorganic nutrients (Experiment 2)}

Twenty-millilitre subsamples were immediately filtered (GF/C, Whatman) to remove algal cells and kept frozen in acid rinsed $20 \mathrm{ml}$ plastic scintillation vials (Packard) until analysis for $\mathrm{N}$ and $\mathrm{P}$ in a ALPKEM RFA (Rapid Flow Analyser).

\section{Statistical analysis}

Analyses of differences between groups were made using ANOVA (and subsequently Newman-Keuls) or $t$-test when normality and equal variance tests were passed. When these tests were not passed, nonnumerical tests (ANOVA on ranks and MannWhitney $U$-test) were used. Also Pearsons product moment correlation analysis and linear regression was used when appropriate. All analyses were carried out using the Sigmastat version 2.0 software package.

\section{Results}

\section{Experiment 1}

Following a lag-phase of 3-4 days, the abundance of both $P$. pouchetii and $R$. salina increased exponentially in all cultures until limited by either virus infection or nutrient availability (Figures 1a and c). When cultivated alone ( $P$. pouchetii control), $P$. pouchetii abundance levelled off on day 14 reaching about $1.1 \times 10^{6}$ cells ml $^{-1}$ (Figure 1a). In the mixed cultures (P. pouchetii $+R$. salina control), P. pouchetii growth ceased on day 9, and the population stabilized at about $7 \times 10^{5} \mathrm{cells} \mathrm{ml}^{-1}$, which was significantly lower than the $P$. pouchetii control ( $t$-test, $P<0.001)$. A similar growth pattern was seen for $R$. salina. In monoculture ( $R$. salina control), $R$. salina abundance stabilized on day 16 at $1.2 \times 10^{5}$ cells ml $^{-1}$ (Figure 1c), whereas in the $P$. pouchetii $+R$. salina control it reached a stationary phase on day 12 and a maximum abundance of $6 \times 10^{4}$ cells $\mathrm{ml}^{-1}$, significantly lower than in the $R$. salina control ( $t$-test, $P<0.001)$. Cocultured with $R$. salina, $P$. pouchetii reached $61 \%$ of the abundance obtained in the single-species culture and for $R$. salina the corresponding percentage was $48 \%$. The net growth rates of $P$. pouchetii and $R$. salina were $0.37 \mathrm{~d}^{-1}$ and $0.36 \mathrm{~d}^{-1}$, respectively, during exponential growth in monocultures.

Addition of $\mathrm{PpV}$ had a pronounced effect on algal growth patterns. In the culture with highest initial virus/alga ratio (v/a 0.5 ), $P$. pouchetii abundance increased until day 6 reaching a maximum abundance of $9 \times 10^{4}$ cells $\mathrm{ml}^{-1}$. At this time the population started to decline and on day 8 the culture was completely lysed. Decreasing the initial virus/alga ratio to 0.005 , caused a significant increase in the maximum $P$. pouchetii abundance 

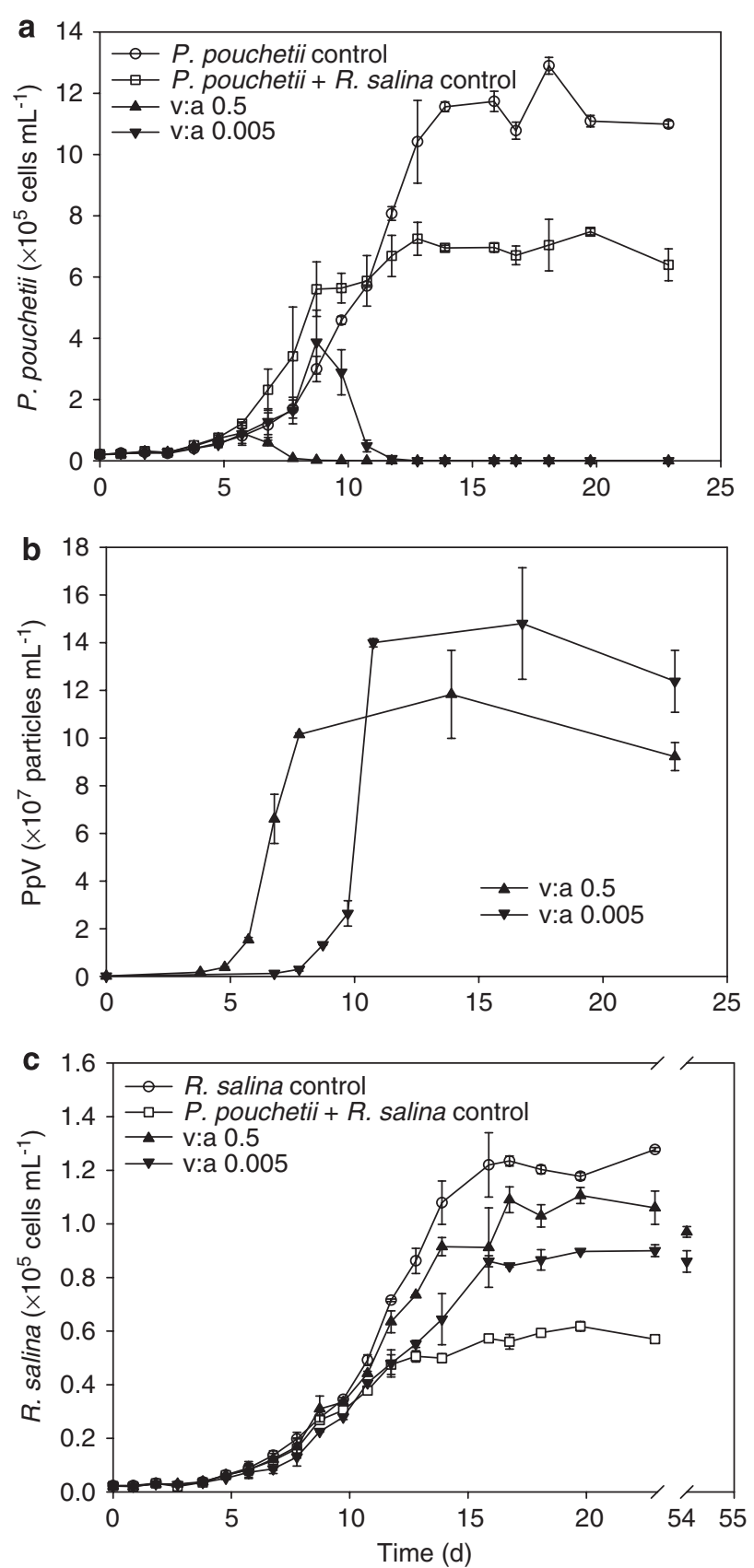

Figure 1 Abundance of $P$. pouchetii (a), $\mathrm{PpV}$ viruses (b) and R. salina (c) in Experiment 1. Open and closed symbols represent cultures without and with addition of viruses on day 0 , respectively. Symbols show average of two replicates. Error bars: s.e. (Error bars are within the size of the symbols when not seen).

$\left(3.9 \times 10^{5}\right.$ cells ml ${ }^{-1}, t$-test, $\left.P=0.005\right)$ before viral lysis eliminated the population on day 12 (Figure 1a). P. pouchetii cells were not observed in any of the cultures following complete lysis.

The time lag from virus addition to incipient lysis of $P$. pouchetii was reflected in the $\mathrm{PpV}$ abundance. $\mathrm{PpV}$ abundance remained low during the first 5 and 8 days respectively for the v/a 0.5 and v/a 0.005 cultures (Figure 1b), and then increased exponentially to between 1.1 and $1.7 \times 10^{8} \mathrm{PpV} \mathrm{ml}^{-1}$ (not significantly different, $t$-test, $P=0.121$ ).
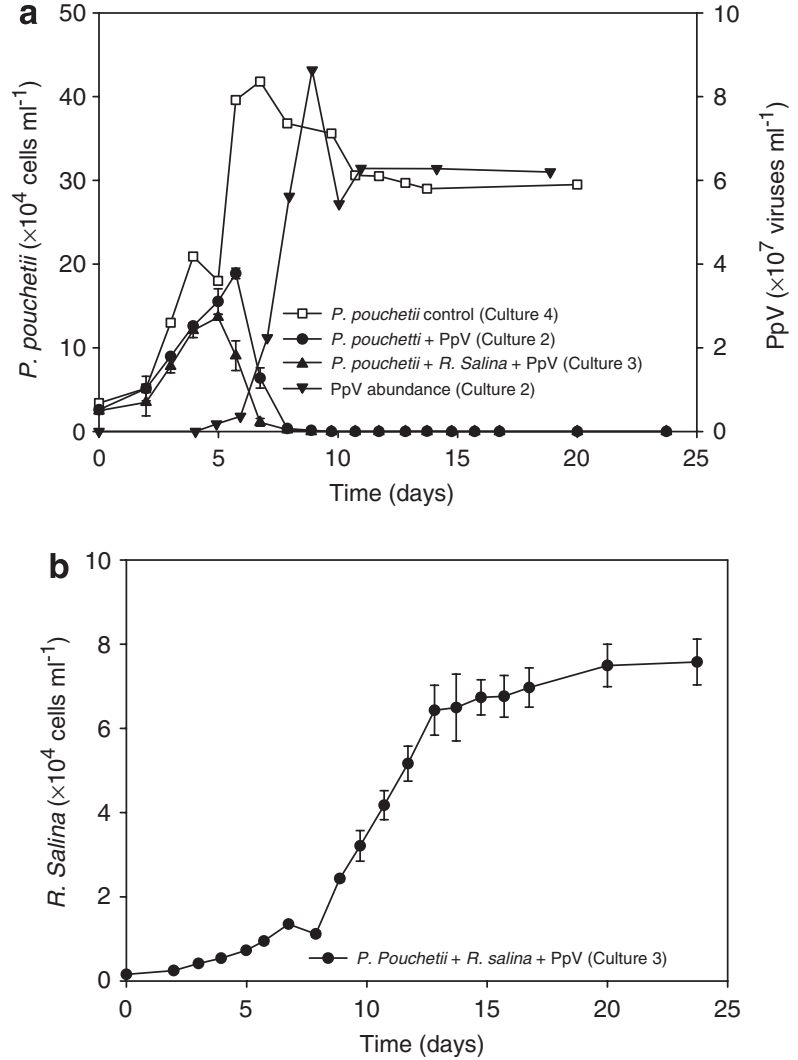

Figure 2 Abundance of $P$. pouchetii and $\mathrm{PpV}$ viruses (a) and $R$. salina (b) in Experiment 2. Open and closed symbols represent cultures without and with addition of viruses on day 0 , respectively. Symbols show average of two replicates. Error bars: s.e. (Error bars are within the size of the symbols when not seen).

All R. salina populations grew equally well until day 10 when they started deviating (Figure 1c). On day 17 all populations had reached significantly different levels (based on data from days 16-23) (one way ANOVA, $P<0.001$, Newman-Keuls, $P<0.001$ for all treatments). In the two virus-amended cultures $R$. salina abundance stabilized at levels intermediate of the two controls. The virusamended cultures were counted again on day 54 where $R$. salina abundance was still stable at the same level (Figure 1c). Abundance levels of the $R$. salina in stationary phase ranged between $6 \times 10^{4}$ and $1.3 \times 10^{5}$ cells ml $^{-1}$.

\section{Experiment 2}

The $P$. pouchetii populations increased exponentially in all $\mathrm{PpV}$-amended cultures during the first $5-6$ days $\left(\mu\right.$ net $=0.41-0.47 \mathrm{~d}^{-1}$ ) reaching abundances prior to viral lysis of $1.2 \times 10^{5}-$ $1.9 \times 10^{5}$ cells ml $^{-1}$ (Figure 2a), with significant higher $P$. pouchetii abundance in the culture 2 $(P$. pouchetii $+\mathrm{PpV})$ than in culture $3(P$. pouchetii + R. salina $+\mathrm{PpV})(P<0.05)$. This increase was followed by a rapid and complete lysis of $P$. pouchetii within 2 days in all cultures, and in the $P$. pouchetii+ $R$. salina culture, $R$. salina replaced $P$. pouchetii 
reaching a constant level of $7.5 \times 10^{4} \mathrm{cell} \mathrm{ml}^{-1}$ after 20 days (Figure 2b). In culture 4 (control), $P$. pouchetii abundances increased to $4.2 \times$ $10^{5}$ cells ml $\mathrm{ml}^{-1}$ at 7 days and remained above $3 \times$ $10^{5}$ cells ml $\mathrm{m}^{-1}$ until 18 days, where the incubation was terminated. Viral abundance in culture 2 increased exponentially as the $P$. pouchetii population declined, to a maximum of $8.6 \times 10^{7} \mathrm{PpVml}^{-1}$ after 9 days (Figure 2a).

Viral lysis of $P$. pouchetii was followed by a dramatic increase in bacterial abundance in both cultures 2 and 3 (Figure 3a). From day 10 onwards bacterial abundance was significantly ( $t$-test, $P=0.015)$ higher in culture $2(P$. pouchetii $+\mathrm{PpV})$ than in culture 3 ( $P$. pouchetii $+R$. salina $+\mathrm{PpV})$ with maximum abundances of $1.15 \times 10^{7}$ and $8.26 \times 10^{6}$ cells ml $^{-1}$, respectively (Figure 3a). Following a decrease, bacterial abundance in culture 2 stabilized at a level of about $2 \times 10^{6}$ cells ml $^{-1}$, which was significantly higher than in culture 3 (based on duplicate data points from days 24-41) ( $t$-test, $P<0.001$ ) (Figure 3a). In culture 4 (control without viruses), bacterial abundance remained below $2.5 \times 10^{6}$ cells ml $^{-1}$ until day 10 and reached a maximum abundance of $3.6 \times 10^{6}$ cells after 14 days (Figure 3a).
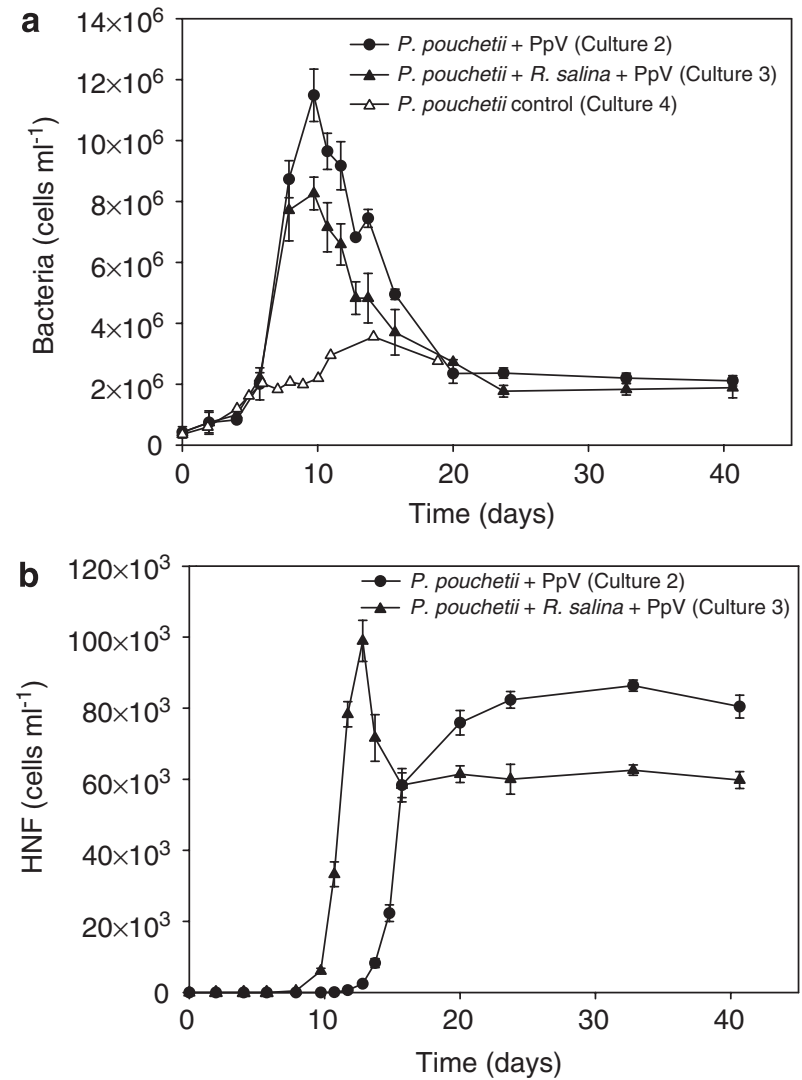

Figure 3 Bacterial abundance (a), and HNF abundance (b) in Experiment 2. Open and closed symbols represent cultures without and with addition of virus on day 0, respectively. Error bars $=$ s.e. (error bars are within the size of the symbols when not seen).
The difference in bacterial abundance between cultures 2 and 3 was reflected in the abundance of HNF (Figure 3b). The HNF population in culture 3 $\left(P\right.$. pouchetii $+R$. salina) increased from $5 \times 10^{3}$ to $1 \times 10^{5}$ cells $\mathrm{ml}^{-1}$ from days $10-13$, before decreasing to a constant level of $6 \times 10^{4}$ cells ml $^{-1}$ (Figure 3b). The 4-day time lag in the HNF growth pattern between the cultures was due to the experimental setup: Relatively large numbers of HNF cells were present in the $R$. salina stock cultures relative to the $P$. pouchetii cultures. The HNF population in culture 3 was therefore capable of a faster response to the increased bacterial numbers than in culture 2, and the two cultures stabilized at $8.6 \times 10^{4}$ and $6.2 \times 10^{4}$ cells ml $^{-1}$, respectively.

The concentration of inorganic $\mathrm{N}\left(\mathrm{NO}_{3}^{-}\right.$and $\left.\mathrm{NH}_{4}^{+}\right)$ and $\mathrm{P} \quad\left(\mathrm{PO}_{4}^{3-}\right)$ was determined in culture 2 (P. pouchetii $+\mathrm{PpV}$ ) and culture 3 (P. pouchetii + $R$. salina $+\mathrm{PpV}$ ) until day 41 . In culture 2 (P. pouchetii $+\mathrm{PpV}), \mathrm{NH}_{4}^{+}$concentration increased from day 12 reaching approximately $0.25 \mathrm{mg} \mathrm{l}^{-1}$ (Figure 4a), whereas in culture 3 ( $P$. pouchetii+ R. salina $+\mathrm{PpV}$ ), $\mathrm{NH}_{4}^{+}$was stable at ca., $0.05 \mathrm{mg} \mathrm{l}^{-1}$ before increasing on day 41 to ca., $0.1 \mathrm{mgl}^{-1}$. $\mathrm{NO}_{3}^{-}$ concentration decreased in culture 2 from $0.6 \mathrm{mg} \mathrm{l}^{-1}$ to below detection limit on day 13. In the same period, the concentration of $\mathrm{NO}_{3}^{-}$decreased in culture 2 from 0.6 to $0.3 \mathrm{mg} \mathrm{l}^{-1}$ where it remained stable until day 41 when sampling for inorganic $\mathrm{N}$ was terminated (Figure 4b). Phosphate concentrations decreased in both cultures from $0.09 \mathrm{mg} \mathrm{l}^{-1}$ to $0.01 \mathrm{mg} \mathrm{l}^{-1}$ during the first $12 \mathrm{~h}$ (Figure 4c). Similar to ammonium, phosphate concentrations in culture 2 then increased and reached $0.03 \mathrm{mg} \mathrm{l}^{-1}$ after $40 \mathrm{~h}$, whereas it remained low in culture 3 (Figure 4c).

In the long-term development in Experiment 2, a regrowth of virus-resistant $P$. pouchetii followed the lysis of the sensitive host population in cultures 1 and 2, whereas a resistant population was not established in culture 3 , which also contained $R$. salina (Figure 5). Owing to a temporal displacement in the appearance of resistant cells between replicate cultures as also found by Thyrhaug et al. (2003), the replicates are not averaged but presented separately. A few $P$. pouchetii cells were observed in culture 3 around days 12-13, but were not observed again after this time (Figure 5c). In culture 1 ( $P$. pouchetii $+\mathrm{PpV}$ in $\mathrm{f} / 2$ medium), resistant cells were first detected on day 26 in replicate $B$ (Figure 5a). In this culture the population increased exponentially for 30 days reaching $5.5 \times$ $10^{5}$ cells $\mathrm{ml}^{-1}$ before it declined a factor $10^{4}$ within 10 days. The culture was then going through a second recovery cycle during the next 30 days until sampling was terminated. Owing to a lower algal net growth rate, replicate A increased with a delay of ca., 10 days. The regrowth pattern in this culture was similar to replicate $B$ except for the lower initial net growth rate, higher maximum abundance $\left(2.2 \times 10^{6} \mathrm{cells} \mathrm{ml}^{-1}\right)$ and faster second recovery (Figure 5a). In culture 2 ( $P$. pouchetii $+\mathrm{PpV}$ 

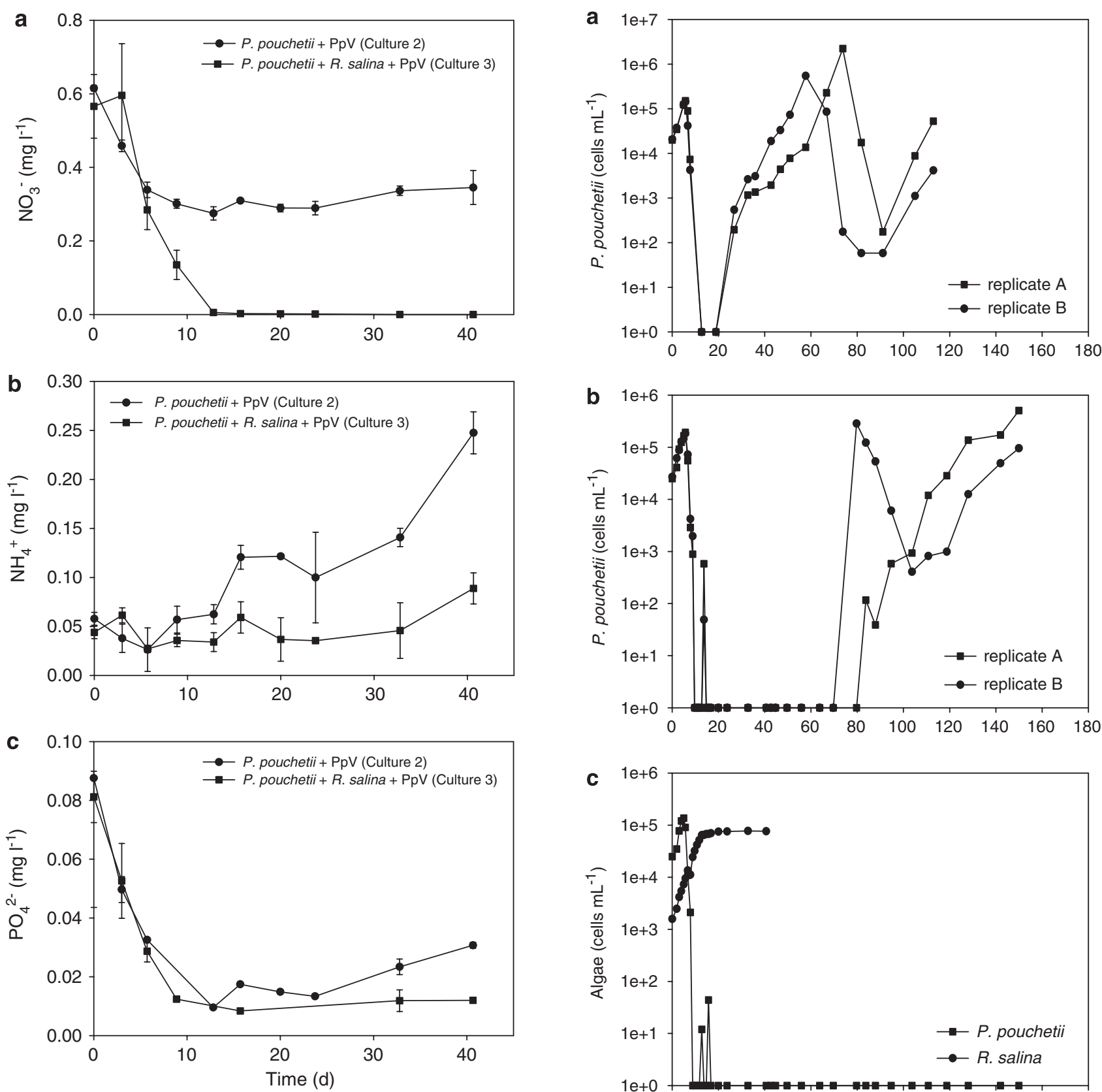

Figure 4 Concentrations of $\mathrm{NH}_{4}^{+}(\mathbf{a}), \mathrm{NO}_{3}^{-}(\mathbf{b})$ and $\mathrm{PO}_{4}^{3-}$ (c) in the SWM cultures (cultures 2 and 3, Experiment 2). Symbols represent average of two replicates, error bars $=$ s.e. (error bars are within the size of the symbols when not seen).

in SWM medium), the resistant population in replicate $\mathrm{B}$ increased from days 70 to 80 from below detection limit to $2.8 \times 10^{5} \mathrm{cells} \mathrm{ml}^{-1}$. This was followed by a decline to just above detection limit during the next 20 days and a second recovery cycle in the following 50 days. Owing to the lack of sampling points between detection limit and maximum cell abundance, it was not possible to calculate the rate of regrowth in this culture. Meanwhile replicate A only experienced one recov-

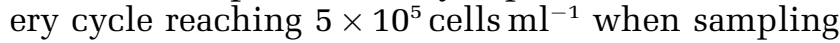
was terminated (Figure 5b).

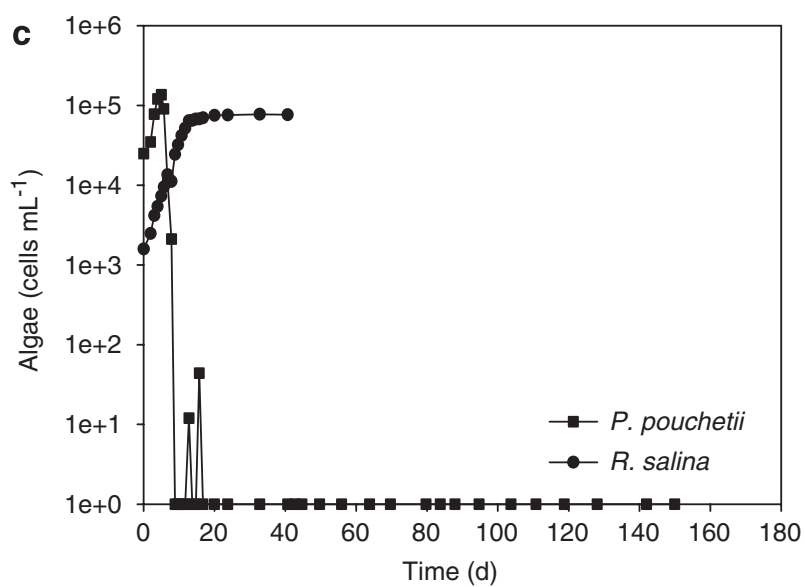

Figure 5 Experiment 2. Long-term development in abundance of $P$. pouchetii growing in $\mathrm{f} / 2$ medium (culture 1) (a), SWM medium (culture 2) (b), and abundance of $P$. pouchetii and $R$. salina in SWM medium (culture 3) (c). Note that the scales on the $y$ axis differ between graphs.

\section{Discussion}

Dynamics of phytoplankton and virus populations The impact of viral lysis on $P$. pouchetii development in the cultures was closely related with initial virus concentration as demonstrated by a significant negative correlation between initial abundance of $\mathrm{PpV}$ and maximum $P$. pouchetii abundance $\left(P<0.001, r^{2}=0.84\right)$. A reduced initial virus/alga ratio resulted in a lower encounter rate and therefore 
also a lower infection rate which in turn resulted in a higher host abundance before lysis. The initial virus and alga concentrations used in this study were lower than in comparable laboratory studies (Bratbak et al., 1998a, 1998b; Thyrhaug et al., 2003), and demonstrate the potential of a very few $\left(<100\right.$ particles $\left.\mathrm{ml}^{-1}\right)$ viruses to terminate an algal bloom, whereas higher initial viral abundances $\left(\sim 10000\right.$ particles $\mathrm{ml}^{-1}$ ) completely prevented the P. pouchetii bloom. Similar lysis patterns were also seen by Bratbak et al. (1998b) in laboratory experiments with $P$. pouchetii and different initial concentrations of $\mathrm{PpV}$.

By preventing $P$. pouchetii from exploiting the available nutrients, viruses stimulated growth of the non-infected $R$. salina. Consequently, increasing initial virus/alga ratios led to higher levels of $R$. salina compared with the two-species control, emphasizing how various levels of viral activity can affect the succession and population dynamics of two algal species, and suggesting that viruses may contribute to the algal succession and their relative distribution in natural marine plankton. The observed influence of viruses on algal dynamics thus provided experimental support for specific viral lysis as a mechanism to maintain species coexistence in phytoplankton communities rather than competitive exclusion, and thus represent a resolution to the Hutchinson's 'The paradox of the plankton' (Hutchinson, 1961).

Heterotrophic response to viral lysis of $P$. pouchetii and implications for nitrogen and phosphorus cycling In Experiment 2, the lysis of $P$. pouchetii was associated with a dramatic increase in bacterial abundance and subsequently HNF abundance. The significantly higher maximum $P$. pouchetii abundance in culture 2 ( $P$. pouchetii $+\mathrm{PpV})$ compared with culture 3 , which also contained $R$. salina led to a higher lysate release, which again was reflected in a significantly higher production of bacteria and HNF in culture 2. From day 10 onwards, the increase in HNF abundance concomitant with a crash of bacterial populations suggested HNF control of the bacterial assemblage in both cultures preventing further increases in bacterial abundance. This coupling between algal lysis and bacterial and HNF abundances demonstrated a direct and efficient transfer of organic matter from the algae to bacteria and HNF through viral lysis. Such energy transfer in the microbial food web through viral lysis of phytoplankton has been documented in various studies (for example, Brussaard et al., 1995, 1996a, 2005a; Gobler et al., 1997; Bratbak et al., 1998b), and confirms that viral lysates may divert organic matter away from the classical grazer food chain, and rather contribute to sustaining heterotrophic activities in the microbial food web (Fuhrman, 1992).

To quantify the fate of the viral lysates and establish a mass balance of the distribution of carbon, nitrogen and phosphorus between the groups of organisms following the lysis event, the measured changes in microbial abundances in cultures 2 and 3 were converted to biomasses and compared with the measured net fluxes of inorganic nitrogen. Using literature values for cellular C, N and $\mathrm{P}$ contents, the $\mathrm{C}, \mathrm{N}$ and $\mathrm{P}$ bound in different compartments and the transfer between them were calculated during the lysis period (days 6-10) and the post-lysis period (days 10-41) (Table 2).

Assuming a cell C- and N content for $P$. pouchetii of $6 \mathrm{pg} \mathrm{C}$ and $1 \mathrm{pg} \mathrm{N}$, respectively (Jacobsen, 2000), the lysate produced during the decrease in $P$. pouchetii abundance from days 6-10 contained $1133 \mu \mathrm{g} \mathrm{CL}^{-1}$ and $189 \mu \mathrm{g} \mathrm{N} \mathrm{I}^{-1}$ in culture 2 and $819 \mu \mathrm{gl}^{-1}$ and $137 \mu \mathrm{g} \mathrm{Nl}^{-1}$ in culture 3 (Table 2). The increase in bacterial $\mathrm{C}$ from days 6 to 10 relative to the control cultures must be balanced by release of lysate C. Of the 1133 and $819 \mu \mathrm{g} \mathrm{CL}^{-1}$ released, $189 \mu \mathrm{g} \mathrm{Cl}^{-1}$ and $121 \mu \mathrm{g} \mathrm{Cl}^{-1}$ were converted to bacterial biomass in cultures 2 and 3, respectively, as estimated from the increase in bacterial abundance over the same period and assuming a bacterial cell carbon content of $0.02 \mathrm{pg}$ (Carlsson et al., 1999). Using the Redfield ratio $(\mathrm{N} / \mathrm{P}=16)$ to estimate the $\mathrm{P}$ content in the lysates, the P-release in cultures 2 and 3 were 26.1 and $19.0 \mu \mathrm{g} \mathrm{I}^{-1}$, respectively, of which 9.3 and $6.0 \mu \mathrm{g} \mathrm{Pl}^{-1}$ were taken up by bacteria (Table 2).

Our calculations suggested a high lability of the released algal lysates. The ratio between the loss of $P$. pouchetii biomass and the subsequent production of bacteria indicated that $15-17 \%$ of the lysate was converted to bacterial biomass (Table 2). Values of bacterial growth efficiencies of $15-17 \%$ are not uncommon (for example, del Giorgio and Cole, 2000 ) suggesting that most of the $P$. pouchetii lysates were taken up by bacteria in the cultures. However, assuming a slightly higher bacterial growth efficiency of $20-30 \%$ (Middelboe et al., 1992), then 50$83 \%$ of the lysates were utilized by the bacteria within 4 days. Considering that bacterial growth was estimated from net cell production, the actual conversion of lysates into bacterial biomass were likely even higher than our estimates (Table 2) as any cell loss due to HNF grazing and viral lysis of bacteria during days 6-10 was not accounted for in the mass balance (Table 2). As we have not estimated viral lysis and HNF grazing during that period, bacterial net growth should therefore be considered a conservative estimate of the actual bacterial uptake in the experiment. However, despite the various assumptions underlying the estimated transfer efficiency and nutrient mineralization, the overall nutrient budget seemed to add up and correspond well with previous studies; all pointing to the potential importance of viral lysates for carbon and nutrient cycling in the microbial food web.

Efficient transfer of organic matter from $P$. pouchetii to bacteria through viral lysis has previously been 
Table 2 Estimated fluxes of C, N and P in P. pouchetii cultures 2 and 3 in Experiment 2

\begin{tabular}{|c|c|c|c|c|c|c|c|c|c|c|}
\hline & & \multicolumn{3}{|c|}{$\mu g N l^{-1}$} & \multicolumn{3}{|c|}{$\mu g P l^{-1}$} & \multicolumn{3}{|c|}{$\mu g C L^{-1}$} \\
\hline & & $\begin{array}{l}\text { +virus } \\
\text { (culture 2) }\end{array}$ & $\begin{array}{l}\quad+\text { virus } \\
+ \text { R. salina; } \\
\text { (culture 3) }\end{array}$ & $\begin{array}{l}\text { Control } \\
\text { (-virus) } \\
\text { (culture 4) }\end{array}$ & $\begin{array}{c}\text { +virus } \\
\text { (culture 2) }\end{array}$ & $\begin{array}{l}\text { +virus; } \\
+ \text { +R. salina } \\
\text { (culture 3) }\end{array}$ & $\begin{array}{l}\text { Control } \\
\text { (-virus) } \\
\text { (culture 4) }\end{array}$ & $\begin{array}{l}\text { +virus } \\
\text { (culture 2) }\end{array}$ & $\begin{array}{l}\quad+\text { virus; } \\
+ \text { R. salina } \\
\text { (culture 3) }\end{array}$ & $\begin{array}{l}\text { Control } \\
\text { (-virus) } \\
\text { (culture 4) }\end{array}$ \\
\hline \multirow[t]{3}{*}{ Day 6-10 } & $\begin{array}{l}\text { Lysate produced } \\
\text { (net decrease of } \\
P \text {. pouchetii) }\end{array}$ & $189 \pm 6$ & $137 \pm 6$ & 0 & $26.1 \pm 0.8$ & $19.0 \pm 0.8$ & 0 & $1133 \pm 37$ & $819 \pm 38$ & 0 \\
\hline & Bacterial net growth & $42 \pm 3$ & $27 \pm 3$ & 0.7 & $9.3 \pm 0.7$ & $6.0 \pm 0.7$ & 0.2 & $189 \pm 15$ & $121 \pm 11$ & 3 \\
\hline & $\begin{array}{l}\text { Carbon conversion } \\
\text { efficiency }\end{array}$ & - & - & - & - & - & - & 0.17 & 0.15 & - \\
\hline \multirow{4}{*}{ Day 10-41 } & Net ammonium release & $148 \pm 20$ & $41 \pm 13$ & ND & - & - & - & - & - & - \\
\hline & Net phosphate release & - & - & - & $6.9 \pm 2.1$ & $1.1 \pm 0.8$ & ND & - & - & - \\
\hline & Bacterial net growth & $-41 \pm 3$ & $-28 \pm 2$ & 11 & $-9.1 \pm 0.7$ & $-6.2 \pm 0.1$ & 1.1 & $-187 \pm 14$ & $-128 \pm 11$ & - \\
\hline & HNF net uptake & $36 \pm 1$ & $26 \pm 3$ & ND & $3.1 \pm 0.1$ & $2.3 \pm 0.3$ & ND & $221 \pm 4$ & $163 \pm 21$ & ND \\
\hline \multirow{4}{*}{$\begin{array}{l}\text { Conversion factors: } \\
\text { P. pouchetii cell }{ }^{-1} \text { : }\end{array}$} & & Reference: & & & & & & & & \\
\hline & $6 \mathrm{pg} \mathrm{C}$ & (Jacobsen, 2000) & & & & & & & & \\
\hline & $1 \mathrm{pg} \mathrm{N}$ & (Jacobsen, 2000) & & & & & & & & \\
\hline & Molar N/P 16 & Redfield ratio & & & & & & & & \\
\hline \multirow[t]{3}{*}{ Bacteria cell $^{-1}$ : } & $20 \mathrm{fg} C$ & (Carlsson et al., 1999) & & & & & & & & \\
\hline & $4.4 \mathrm{fg} \mathrm{N}$ & (Carlsson et al., 1999) & & & & & & & & \\
\hline & Molar N/P 10 & (Vrede et al., 2002) & & & & & & & & \\
\hline \multirow[t]{3}{*}{ HNF cell ${ }^{-1}$ : } & $2.6 \mathrm{pg} \mathrm{C}$ & $\begin{array}{l}\text { (Menden-Deuer } \\
\text { and Lessard, 2000) }\end{array}$ & & & & & & & & \\
\hline & $0.42 \mathrm{pg} \mathrm{N}$ & (Verity et al., 1992) & & & & & & & & \\
\hline & Molar N/P 25 & (Grover, 2003) & & & & & & & & \\
\hline
\end{tabular}


demonstrated by Bratbak et al. (1998a), and also Brussaard et al. (1996a), found that release of viral lysates following a Phaeocystis bloom in the North Sea could account for more than the bacterial carbon demand. Similarly, Gobler et al. (1997) found that viral lysis of an Aureococcus anophagefferens bloom in the field released $\sim 500 \mu \mathrm{gCl}^{-1}$ and supported bacterial demands for both carbon and nutrients. Previous studies have also found bacterial lysates to be efficiently utilized by other bacteria, as demonstrated by Middelboe et al. (2003) in a study showing that $>62 \%$ of a bacterial lysate was metabolized by other bacteria following viral lysis within a few days, assuming a bacterial growth efficiency of $45 \%$.

Approximately $20 \%$ of the lysate $\mathrm{N}$ was accumulated in bacterial biomass during the first 4 days after cell lysis, and following the decrease in bacterial abundance from days 10-20, about $90 \%$ of the bacterial $\mathrm{N}$ was converted into HNF biomass. Over the whole course of the 41 days experiment, $78 \%$ of the estimated lysate $\mathrm{N}$ was mineralized in culture 2, indicating an efficient heterotrophic $\mathrm{N}$ mineralization associated with lysate turnover in the microbial food web. In total, $97 \%$ of the estimated lysate $\mathrm{N}$ in culture 2 was recovered either as $\mathrm{NH}_{4}^{+}$or as bacteria and HNF biomasses at the end of the experiment, suggesting that accumulation of refractory dissolved organic $\mathrm{N}$ in the viral lysates was insignificant.

For phosphorus, only $26 \%$ of the $P$ content in the viral lysates was released as $\mathrm{PO}_{4}^{3-}$ following the decrease in bacterial numbers from days 10-41 (Table 2), and $38 \%$ of the total lysate $P$ could be accounted for as $\mathrm{PO}_{4}^{3-}$ or $\mathrm{HNF}$ biomass. This suggested that $P$ was mineralized less efficiently than $\mathrm{N}$ and that a significant fraction of the lysate $P$ remained as dissolved organic phosphorus throughout the incubation.

Of the $137 \mu \mathrm{g} \mathrm{N}$ that was released as $P$. pouchetii lysates in culture $3,41 \mu \mathrm{g} \mathrm{N}$ were mineralized to $\mathrm{NH}_{4}^{+}$, whereas the remaining $96 \mu \mathrm{g} \mathrm{Nl}^{-1}$ were presumably taken up by the $R$. salina population, as indicated by the evidence for nitrogen limitation of $R$. salina growth after day 12 (Figure $4 \mathrm{~b}$ ). Assuming a cell $\mathrm{N}$ content of $1.14 \times 10^{5} \mu \mathrm{g} \mathrm{N}$ cell ${ }^{-1}$ (Montagnes et al., 1994), the estimated $\mathrm{N}$-input from the lysates supported the production of $8.4 \times 10^{3} \mathrm{cells} \mathrm{ml}^{-1}$, corresponding to $11 \%$ of the maximum $R$. salina abundance in the culture. Our data thus support previous results by Gobler et al. (1997), which showed that inoculation of viral lysates to nutrient-limited diatom cultures caused alleviation of the nutrient limitation. Unlike in this study, viral lysis was in that case not associated with mineralization of $\mathrm{N}$ and $\mathrm{P}$ and the observed stimulation of algal growth rate and biomass in response to algal lysis was proposed to be mainly in the form of organic nutrients (Gobler et al. 1997). In general, this study contributes to the emerging evidence that viral lysis may be an important mechanism promoting heterotrophic nutrient cycling and thus stimulating primary production (for example, Brussaard et al., 2008; Middelboe, 2008).

\section{Regrowth of resistant $P$. pouchetii}

The net growth rate of the resistant $P$. pouchetii cells that appeared following viral lysis was in general significantly lower than that of the wild type ( $\mu$-net $=43-75 \%$ compared to the wild type). This supports the observations by Thyrhaug et al. (2003) who found a $50 \%$ reduction in net growth rate of resistant algae, and suggests a reduced growth capacity of resistant strains. Reduced net growth rate of resistant clones has previously been observed for heterotrophic bacteria (Middelboe, 2000). For bacteria, the phenomenon has been ascribed to modifications in the membrane structures, which affected both viral attachment and the cell's ability to take up specific substrate (Lenski, 1988) and a broad range of mutations that confer phage resistance would be expected to alter the growth rate of the mutant. Likewise for algae, many types of mutations rendering the cell resistant to viruses are likely to affect growth rates. It is thus possible that the difference in rates of re-growth between otherwise identical replicates (Figures $5 \mathrm{a}$ and b) reflects the re-growth of genetically distinct mutants with different growth rates. However, the molecular nature of these mutations was not revealed. In this study, we found indications that the reduced competitiveness of the virus-resistant algae was related to their ability to take up nutrients. The time from lysis to incipient regrowth was inversely correlated to the nutrient availability. Regrowth started 50 days earlier in the nutrient rich $\mathrm{f} / 2$ medium compared with the less rich SWM medium, despite relatively high nutrient concentrations even in SWM following lysis. Nutrient concentration never becomes limiting for algal growth in $\mathrm{f} / 2$ medium as increased $\mathrm{pH}$ will always set the upper limit for $P$. pouchetii and $R$. salina growth before the inorganic nutrients are used up (data not shown). Therefore, although we have not measured inorganic $\mathrm{N}$ and $\mathrm{P}$ concentrations during that part of the experiments, nutrient concentrations were likely to be much higher in culture 1 than in cultures 2 and 3 . Lower nutrient concentrations in culture 2 may, therefore be part of the explanation for the observed delay in regrowth of resistant $P$. pouchetii, if resistant cells had lower affinity for inorganic nutrients and therefore were less efficient in utilizing them than the wild type. However, these are only speculations, as the underlying mechanisms of algal resistance to viruses have not yet been identified, and as other factors may have delayed the regrowth of $P$. pouchetii in SWM medium compared with $\mathrm{f} / 2$ medium.

The complete lack of growth of resistant $P$. pouchetii in the presence of a competing alga in the present study (Figure 5c), however, suggests that 
the probability of establishing abundant populations of these resistant types following lysis in a mixed natural community are small.

\section{Ecological considerations}

The experiments demonstrated extensive effects of a species-specific virus on algal population dynamics and heterotrophic nutrient regeneration. The simplified model system used allowed us to address specific questions about microbial interactions during lysis of an algal bloom, and to make a mass balance for carbon, nitrogen and phosphorus fluxes during and following viral lysis of a $P$. pouchetii population. Although results from such simple systems cannot be directly extrapolated to natural pelagic marine systems, they clearly demonstrated a number of important mechanisms influencing the succession of phytoplankton species. Furthermore, we have provided experimental evidence that viruses may be a significant driving force in nutrient regeneration, and consequently stimulation of marine primary production. Still many open questions remain to be investigated to understand and describe the dynamics of natural communities of algae and virus. These include clonal variation of algae and viruses and the molecular nature of the mechanisms leading to virus resistance, which may constitute two important areas in future research.

\section{Acknowledgements}

We thank G Bratbak and A Larsen from University of Bergen for their help and for providing the $P$ pouchetii alga and its virus. We also thank Niels Henrik Borch and Nils Willumsen from University of Copenhagen for help with flowcytometry and nutrient analyses. Three anonymous reviewers provided very valuable comments and input to the article. This work was supported by grants from the Danish Natural Sciences Research Council and the Carlsberg Foundation.

\section{References}

Bratbak G, Egge J, Heldal M. (1993). Viral mortality of the marine alga Emiliania huxleyi (Haptophyceae) and termination of algal blooms. Mar Ecol Prog Ser 93: 39-48.

Bratbak G, Levasseur M, Michaud S, Cantin G, Fernández E, Heimdal BR, Heldal M. (1995). Viral activity in relation to Emiliania huxleyi blooms: a mechanism of DMSP release? Mar Ecol Prog Ser 128: 133-142.

Bratbak G, Jacobsen A, Heldal M. (1998a). Viral lysis of Phaeocystis pouchetii and bacterial secondary production. Aquat Microb Ecol 16: 11-16.

Bratbak G, Jacobsen A, Heldal M, Nagasaki K, Thingstad TF. (1998b). Virus production in Phaeocystis pouchetii and its relation to host cell growth and nutrition. Aquat Microb Ecol 16: 1-9.
Bratbak G, Thingstad TF, Heldal M. (1994). Viruses and the microbial loop. Microb Ecol 28: 209-221.

Brussaard CPD, Bratbak G, Baudoux A-C, Ruardij P. (2007). Phaeocystis and its interaction with viruses. Biogeochem 83: 201-215.

Brussaard CPD, Gast GJ, Van Duijl FC, Riegman R. (1996a). Impact of phytoplankton bloom magnitude on a pelagic microbial food web. Mar Ecol Prog Ser 144: 211-221.

Brussaard CPD, Mari X, Van Bleijswijk JDL, Veldhuis MJW. (2005a). A mesocosm study of Phaeocystis globosa (Prymnesiophyceae) population dynamics II: Significance for the microbial community. Harmful algae 4: 875-893.

Brussaard CPD, Kuipers B, Veldhuis MJW. (2005b). A mesocosm study of Phaeocystis globosa population dynamics I: Regulatory role of viruses in bloom control. Harmful algae 4: 859-874.

Brussaard CPD, Riegman R, Noordeloos AAM, Cadée GC, Witte H, Kop AJ, Nieuwland G, van Duyl FC, Bak RPM. (1995). Effects of grazing, sedimentation and phytoplankton cell lysis on the structure of a coastal pelagic food web. Mar Ecol Prog Ser 123: 259-271.

Brussaard CPD, Kempers RS, Kop AJ, Riegman R, Heldal M. (1996b). Virus-like particles in a summer bloom af Emiliania huxleyi in the North Sea. Aquat Microb Ecol 10: 105-113.

Brussaard CPD, Wilhelm SW, Thingstad TF, Weinbauer MG, Bratbak G, Heldal M et al. (2008). Global scale processes with a nanoscale drive-the role of marine viruses. ISME J 2: 575-578.

Carlsson P, Granéli E, Segatto AZ. (1999). Cycling of biologically available nitrogen in riverine humic substances between marine bacteria, a heterotrophic nanoflagellate and a photosynthetic dinoflagellate. Aquat Microb Ecol 18: 23-36.

Castberg T, Larsen A, Sandaa RA, Brussaard CPD, Egge J, Heldal MG et al. (2001). Microbial population dynamics and diversity during a bloom of the marine coccolithophorid Emiliania huxleyi (Haptophyta). Mar Ecol Prog Ser 221: 39-46.

Comeau AM, Chan AM, Suttle CA. (2006). Genetic richness of vibriophages isolated in a coastal environment. Environm Microbiol 8: 1164-1176.

del Giorgio PA, Cole JJ. (2000). Bacterial energetics and growth efficiency. In: Kirchman, DL (ed). Microbial Ecology of the Oceans. Wiley: New York, pp 289-326.

Fuhrman JA. (1992). Bacterioplankton roles in cycling of organic matter: the microbial food web. In: Falkowski PG, Woodhead AD (eds). Primary productivity and biogeochemical cycles in the sea. Plenum Press: New York, pp 361-382.

Gobler CJ, Hutchins DA, Fisher NS, Cosper EM, SañudoWilhelmy SA. (1997). Release and bioavailability of C, $\mathrm{N}$, P, Se and Fe following viral lysis of a marine chrysophyte. Limnol Oceanogr 42: 1492-1504.

Grover JP. (2003). The impact of variable stoichiometry on predator-prey interactions: a multinutrient approach. Amer Nat 162: 29-43.

Guillard RRL. (1975). Culture of phytoplankton for feeding marine invertebrates. In: Smith WL, Chanley $\mathrm{MH}$ (eds). Culture of marine invertebrate animals. Plenum Press: New York, pp 29-60.

Holmfeldt K, Middelboe M, Nybroe O, Riemann L. (2007). Large variability in host strain susceptibility and phage host-range govern interactions between lytic marine phages and their Flavobacterium host'. Appl Environ Microbiol 73: 6730-6739. 
Hutchinson GE. (1961). The paradox of the plankton. Am Nat 95: 137-145.

Jacobsen A. (2000). New aspects of bloom dynamics of Phaeocystis pouchetii (Haptophyta) in Norwegian waters. PhD dissertation. University of Bergen: Norway.

Jacquet S, Heldal M, Iglesias-Rodriguez D, Larsen A, Wilson HW, Bratbak G. (2002). Flow cytometric analysis of an Emiliania huxleyi bloom terminated by viral infection. Aquat Microb Ecol 27: 111-124.

Larsen A, Castberg T, Sandaa RA, Brussaard CPD, Egge J, Heldal $\mathrm{M}$ et al. (2001). Population dynamics and diversity of phytoplankton, bacteria and viruses in a seawater enclosure. Mar Ecol Prog Ser 221: 47-57.

Lennon JT, Khatana SAM, Marston MC, Martiny JBH. (2007). Is there a cost of virus resistance in marine cyanobacteria? ISME J 1: 300-312.

Lenski RE. (1988). Experimental studies of pleiotropy and epistasis in Escherichia coli. I. Variation in competitive fitness among mutants resistant to virus $\mathrm{T} 4$. Evolution 42: 425-432.

Menden-Deuer S, Lessard EJ. (2000). Carbon to volume relationships for dinoflagellates, diatoms, and other protist plankton. Limnol Oceanogr 45: 569-579.

Middelboe M. (2000). Bacterial growth rate and marine virus-host dynamics. Microb Ecol 40: 114-124.

Middelboe M. (2008). Microbial disease in the sea: Effects of viruses on marine carbon and nutrient cycling. In: Ostfeld RS, Keesing F, Eviner VT (eds). Infectious disease ecology: effects of ecosystems on disease and of disease on ecosystems. Princeton University Press: Princeton, NJ, pp. 242-259.

Middelboe M, Hagstrom A, Blackburn N, Sinn B, Fischer U, Borch NH et al. (2001). Effects of bacteriophages on the population dynamics of four strains of pelagic marine bacteria. Microb Ecol 42: 395-406.

Middelboe M, Nielsen B, Søndergaard M. (1992). Bacterial utilization of dissolved organic carbon (DOC) in coastal waters-determination of growth yield. Arch Hydrobiol Beih Ergebn Limnol 37: 51-61.

Middelboe M, Riemann L, Steward GF, Hansen V, Nybroe O. (2003). Virus-induced transfer of organic carbon between marine bacteria in a model community. Aquat Microb Ecol 33: 1-10.

Mizoguci K, Morita M, Fischer CR, Yoichi M, Tanji Y, Unno H. (2003). Coevolution of Bacteriophage PP01 and Escherichia coli O157:H7 in continous culture. Appl Environ Microbiol 69: 170-176.

Montagnes DJS, Berges JA, Harrison PJ, Taylor FJR (1994). Estimating carbon, nitrogen, protein and chlorophyll a from volume in marine phytoplankton. Limnol Oceanogr 39: 1044-1060.
Noble RT, Fuhrman JA. (1998). Use of SYBR Green I for rapid epifluorescence counts of marine viruses and bacteria. Aquat Microb Ecol 61: 333-340.

Poorvin L, Rinta-Kanto JM, Hutchins DA, Wilhelm SW. (2004). Viral release of iron and its bioavailability to marine plankton. Limnol Oceanogr 49: 1734-1741.

Porter KG, Feig YS. (1980). The use of DAPI for identifying and counting aquatic microflora. Limnol Oceanogr 25: 943-948.

Rothhaupt KO. (1992). Stimulation of phosphoruslimited phytoplankton by bacterivorous flagellates in laboratory experiments. Limnol Oceanogr 37: 750-759.

Schroeder DC, Oke J, Hall M, Malin G, Wilson HW. (2003). Virus succession observed during an Emiliania huxleyi bloom. Appl Environ Microbiol 69: 2484-2490.

Stenholm AR, Dalsgaard I, Middelboe M. (2008). Isolation and characterization of bacteriophages infecting the fish pathogen Flavobacterium psychrophilum. Appl Environm Microbiol 74: 4070-4078.

Suttle CA, Chan AM. (1994). Dynamics and distribution of cyanophages and their effect on marine Synechococcus spp. Appl Environ Microbiol 60: 3167-3174.

Tarutani K, Nagasaki K, Yamaguchi M. (2000). Viral impacts on total abundance and clonal composition of the harmful bloom-forming phytoplankton Heterosigma akashiwo. Appl Environ Microbiol 66: 4916-4920.

Thyrhaug R, Larsen A, Thingstad TF, Bratbak G. (2003). Stable coexistence in marine algal host-virus systems. Mar Ecol Prog Ser 254: 27-35.

Vaulot D. (1989). CYTOPC: Processing software for flow cytometric data. Signal and Noise 2: 8.

Verity P, Robertson CY, Tronzo CR, Andrews MG, Nelson JR, Sieracky ME. (1992). Relationships between cell volume and the carbon and nitrogen content of marine photosynthetic nanoplankton. Limnol Oceanogr 37: 1434-1446.

Vrede K, Heldal M, Norland S, Bratbak G. (2002). Elemental Composition (C, N, P) and Cell Volume of Exponentially Growing and Nutrient-Limited Bacterioplankton. Appl Environ Microbiol 68 2965-2971.

Waterbury JB, Valois FW. (1993). Resistance to co-occuring phages enables marine Synechococcus communities to coexist with cyanophages abundant in seawater. Appl Environ Microbiol 59: 3393-3399.

Zingone A, Sarno D, Forlani G. (1999). Seasonal dynamics in the abundance of Micromonas pusilla (Prasinophyceae) and its viruses in the Gulf of Naples (Mediterranean Sea). J Plankton Res 21: 2143-2159. 